\title{
This Tiny Invader
}

Inversions and Connections across Multiple Worlds

\author{
Karel Arnaut \\ University of Leuven, Leuven, Belgium \\ karel.arnaut@kuleuven.be \\ Jack Boulton \\ University of Leuven, Leuven, Belgium \\ jack.boulton@kuleuven.be
}

The ongoing Corona crisis, like any situations of breakdown and turbulence, can be conceptualised in terms of 'infrastructural inversion'. Coined, I think, by Geoffrey Bowker (1994) and later elaborated together with Susan Leigh Star (Bowker and Star 1999), the term in its broadest sense refers to a gestalt switch. The inversion makes the underlying structures, the '(back)ground' visible, for us to realise the important work that infrastructures have been doing all along while slowly 'fading into the woodwork' and increasingly constituting the normal or the natural order/functioning of things. For Bowker and Star infrastructural inversion was above all a strategy deployed by the researcher for instance in debunking certain 'mythologies' and normativities - but more recently, Atsuro Morita (2017: 740) has pointed out that during moments of breakdown, "many people [...] directly affected [...] may begin exploring its ramifications" - leading, to what Morita calls "ontological experiments".

While the visualisation of the ongoing Corona crisis remains to be properly analysed, our overall impression is that, for obvious reasons, the victims themselves, the ill and the dead, were less visible than the spaces and places where they were treated, quarantined, buried, kept away from or queued-up. This may have triggered however the infrastructural awareness of large publics.

All around Europe we saw images of empty city streets designed for the sole purpose of accommodating suffocatingly large numbers of cars - now mostly absent. In contrast, from New Delhi harrowing images circulated of hundreds of thousands migrant workers filling over their entire width and as far as the eye could see roads leading out of the capital after the government suddenly announced a three week lockdown. This exposed the sheer magnitude of the precarious labour force whose zone of care and survival (in other words, repro- 
duction) was far removed from their zone of exploitative production in the capital.

We remember the images of refrigerator trucks storing the bodies of deceased Covid-19 victims outside New York hospitals - indicating in more than one way that the health infrastructures were exceeded. From Africa, we recall the image of a large empty tent in the commune of Yopougon in Abidjan (Côte d'Ivoire), stripped-down by protesters who wanted to prevent it from being converted into a coronavirus testing facility. One of the protesters explained that most of the Corona victims so far (early April) were either white or travelling rich people from more affluent communes such as Cocody; it was hazardous, he explained, to bring them over to the densely populated poorer part of the Ivorian capital.

Each of these images comes with an emerging, and of course divergent and contested, awareness of what has co-produced it: obviously the virus, but by the same token, the entrenched privileges, disinvestments and inequalities on which it could thrive. Perhaps such visceral infrastructural inversions were objectified by the intensive mediatisation of graphic material such as lists, diagrams and charts, but importantly also maps showing unequal distribution of victims across city neighbourhoods, regions and the world as a whole - for everyone to see.

The way in which Africans, Africa and the African diaspora has come into sight in the course of the last months is, to say the least, revealing.

In her intervention during ROAPE webinar on Africa and the Pandemic: Clampdown, Survival and Resistance, ${ }^{1}$ anthropologist Heike Becker (UWC) speaking from Cape Town - opened with reflections on two issues of (in)visibility: firstly, the absence of Arabs in Camus' much-acclaimed pandemic novel The Plague (La Peste, 1947) set in the Algerian city of Oran, then under French colonial rule. Secondly, Becker noted that in the current pandemic "South Africa's impoverished majorities have suddenly become visible, they have been standing in kilometres long lines waiting for food parcels."

Similar imagery of endless queues leading to food banks in the US have come to us, accompanied by disturbing bits of statistics such as "Black people make up $12 \%$ of Michigan's population - and at least $40 \%$ of its coronavirus deaths"; (Neavling 2020), figures that may be extrapolated to large parts of the US (Maqbool 2020). At the time of writing, there is no immediate access to figures concerning new migrants, 11 million undocumented, but we know from

1 Available at http://roape.net/2020/o5/14/africa-and-the-pandemic-clampdown-survival -resistance/. 
Mary Waters (2013) that analyses in terms of racism (Patton 2020) and racial categorisations embellish the situation of the post-197os (Black) migrants as compared to the old diaspora.

These patterns are also apparent when considering the new African diaspora in other parts of the world: for example Somali in Europe (Omar 2020) in general and in the UK in particular (Einash 2020). In China, Human Rights Watch (2020) reported discrimination against African residents in forced quarantines, evictions, and the refusal of services in Guangzhou. In Israel, alarming stories have emerged concerning some 36,ooo African asylum seekers, the majority of whom have never gained refugee status. Although many had been forced to flee their home countries to avoid war or other humanitarian crises, they live in Israel on temporary visas that are periodically renewed. Without clear guidelines and with healthcare provision out of reach, their situation has become even more precarious with loss of jobs and fear of infection compounding already difficult circumstances.

All of these reports highlight the vulnerability of people worldwide: their legal status, reduced access to health provisions, and increased exposure to Covid-19 due to frequent working in 'frontline' jobs. Whilst these are certainly not new issues, they both become visible and are exacerbated by the intrusion of this paradoxically invisible, tiny, invader. More than ever we witness how these issues reverberate globally, across diasporic spaces worldwide. It is well known that a large proportion of diaspora dweller's income is sent back to relatives on the African continent, contributing significantly to the GDP of several sub-Saharan African countries including DR Congo and Zimbabwe (Onyango 2020). This financial redistribution has taken a large 'hit' throughout the current pandemic, with remittances unlikely to recover quickly, even when the pandemic slows (Vinga 2020).

It was feared that Covid-19 would have a devastating impact in African countries, in part at least due to the fragile nature of many healthcare systems and infrastructures on the continent (Makoni 2020). Indeed, the measures taken to control the spread of the virus were in themselves considered problematic: the effects of isolation on poor and vulnerable communities was not well considered, despite the implementation of lockdowns in many parts of subSaharan Africa (Izar et al. 2020). NGOs feared for breaches of human rights, and excessive use of force was noted in South Africa, DR Congo, and Nigeria, among others (Châtelot 2020). Some called for 'Western intervention' in what was predicted to be another 'brewing African catastrophe' (Holmes et al. 2020).

Nonethless, Africa itself is considered an often overlooked 'success story' in terms of its handling of Covid-19 (French 2020). Both infections and deaths 
have remained relatively low, if still significant (Makoni 2020). Whilst maintaining the balance between containment of the virus (on the one hand) and the continued operation of economies which depend, in many cases, on both movement and social contact (on the other) was never an easy task (Zane 2020), Africa's Covid response is now touted as a lesson to us all (Pilling 2020).

Yet, what does this apparent success say about these remittances as a form of wealth redistribution, one which is larger than international 'aid' itself? De Bruyn (2017) describes how remittances are not just cash transactions alone, but can also be described as both symbolic messages of financial inclusion, whilst also adding economic 'visibility' to otherwise invisible pathways for the transference of not just money but also ideas and inspiration. Indeed, these pathways work in both directions: ideas and inspiration can flow just as easily to the diaspora as it can to Africa.

And whilst these financial transactions are certainly important - they feed, clothe and school those in often financially dire circumstances (De Bruyn 2017) - their recent reduction also highlights the creativity and resourcefulness of African people to adapt, build and survive in extreme situations. Whilst the overarching media image of Africans in light of the new coronavirus has been one of pity - for the possibility of mass hunger and death, and the presentation, again, of 'the problem of Africa' (Ferguson 2006) - the reality is that Africa has handled the impact of Covid-19 much better than most other places, despite the apparent lack of resources. The public conversation seems to reinforce the notion of African dependency, yet so far at least the calls for (more) Western intervention have been unnecessary.

\section{Ontological Experiments}

Covid-19 lends additional relevance to Ghassan Hage's characterisation of the diasporic condition as 'lenticular' - as constituted by multiple realities that can be and are intertwined at specific moments and places, and which a person can inhabit simultaneously (Hage in press). Diasporic chronotopes, in Hage's view are constituted by multiple realities that exist in parallel, and it only takes a slight change of perspective to move from one to the other. A similar image is conjured up by AbdouMaliq Simone's "combinatorial spaces" as "special intercallary entities [...] in an intersection of simultaneities, gatherings, convergence, and encounters" (Simone 2004: 242; see also: Arnaut, Karrebæk, and Spotti 2016).

Marilyn Strathern (1991) points out that figure and ground do not relate to each other in a part-whole relationship constituting some kind of totality: 
Insofar as figure-ground reversal presents ground as potential figure, the movement implies that figures 'cut out' of the ground are not figures added to it. But nor are they fragments, and this is not a part-whole relationship. Rather, figure and ground work as two dimensions. They are self-scaling - not two perspectives as it were, but a perspective seen twice, ground as another figure, figure as another ground.

STRATHERN 1991: 113

In that way, people are not just 'essential workers', or 'frontline staff', but they are also friends, wives, husbands, parents and children: all inhabiting the same physical space as multiple aspects of the same person, each one a community in themselves (De Boeck, Cassiman and Van Wolputte 2010).

The ongoing Corona crisis forces us to think in terms of relationships, relatedness and multitudes of kin connections, "dropping threads and failing but sometimes finding something that works, something consequential and maybe even beautiful, that wasn't there before, of relaying connections that matter" (Haraway 2016: 10), things which we can only experience in partiality yet are always present.

In that sense, whilst certainly revealing both old/new vulnerabilities and interconnections, Covid-19 - as a microscopic invader, a coloniser for which so far the only real protection has been new forms of sociality - acts as an interscalar vehicle (Hecht 2018), a 'thing' which allows us to make meaningful connections between the micro- and the macro-levels of analysis, to move through different scales and registers, and which inspires (and forces) new ways of thinking in times which present new and unusual circumstances (Tsing et al. 2017).

And so, as Strathern (1991) indicates, we move through fractals of existence the cutting of relationships through enforced isolation is both a destructive and a creative act. Covid-19 is an invader, but it is one which insists that we reexamine our relationships, hopefully reconfiguring them in new and inclusive ways. "In the elaboration of relationships, it is the elaborations that increase, not the relationships" (Strathern 1991: 113).

It is apt that this special issue considers 'digital diasporas', as many of our connections have moved towards the digital, and the online in particular. Planned before the current pandemic, the topic takes new relevance in a Covid19 world. Yet as the issue reminds us, it is never possible to become completely digital, there are always people entangled with the screen, and behind the pixels. 
African Diaspora welcomes three new editors:

Kalyango Ronald Sebba is a lecturer at the School of Women and Gender Studies and the Department of Social Work and Social Administration, Makerere University, Kampala Uganda. His work explores migration in particular forced migration in Uganda and the Greater Horn of Africa.

Dr. Mary B. Setrana is a Senior lecturer at the Centre for Migration Studies (CMS), University of Ghana (UG), Legon, and a Research Associate at the Department of Sociology, University of Johannesburg, South Africa. Her research interests include transnational migration and diaspora, gender and migration, return and reintegration. She has a courtesy appointment at the School of Interdisciplinary Global Studies at University of South Florida, USA and is a fellow at the African Studies Centre. She has published widely both nationally and internationally.

Sarah Fila-Bakabadio is an historian, Associate Professor in American and African American studies at the CY Cergy Paris Universite (France) and member of the research center AGORA. Her work explores the African diasporas from the Black Atlantic: she studies the intellectual, cultural, and political circulations of African-Americans, Africans and Afro-Europeans from the 19th to 21st centuries.

\section{References}

Arnaut, Karel, Martha Karrebæk, and Massimiliano Spotti. 2016. 'Engaging superdiversity: The poiesis-infrastructure nexus and language practices in combinatorial spaces'. In Engaging superdiversity: Recombining spaces, times and language practices, edited by Karel Arnaut, Martha Karrebæk and Massimiliano Spotti. Bristol: Multilingual Matters.

Bowker, Geoffrey. 1994. 'Information mythology: The world of/as information'. In Information acumen: The understanding and use of knowledge in modern business, edited by L. Bud-Frierman. London: Routledge. Pp. 231-247.

Bowker, Geoffrey and Susan Leigh Star. 1999. Sorting things out: Classification and Its consequences. Cambridge, MA: MIT Press.

Châtelot, Christophe. 2020. 'Coronavirus: en Afrique, des mesures d'exception qui menacent les libertés publiques'. Le Monde. Available at https://www.lemonde .fr/afrique/article/2020/04/13/coronavirus-en-afrique-des-mesures-d-exception -qui-menacent-les-libertes-publiques_6o36443_3212.html. Accessed 8 November 2020.

De Boeck, Filip, Ann Cassiman and Steven Van Wolputte. 2010. 'An anthropology of secondary cities in Africa: Experiences, challenges and new connections'. In African 
Perspectives2oog. The African city: (Re)sourced, edited by K. Bakker. Pretoria: University of Pretoria, Department of Architecture.

De Bruyn, Tom. 2017. Remittances from Belgium as a lever for development. Leuven: HIVA Research Institute for Work and Society.

Einashe, Ismail. 2020. 'Coronavirus: Somali diaspora sends home stories of woe'. вBC News. Available at https://www.bbc.com/news/world-africa-52300410. Accessed 7 November 2020.

French, Howard W. 2020. 'Africa Is a Coronavirus success story so far, If only the world would notice'. World Politics Review. Available at

https://www.worldpoliticsreview.com/articles/28776/africa-is-a-coronavirus-success -story-so-far-if-only-the-world-would-notice. Accessed 7 November 2020.

Ferguson, James. 2006. Global shadows: Africa in the neoliberal world order. Durham: Duke University Press.

Hage, Ghassan. in press. The diasporic condition: ethnographic explorations of the Lebanese in the world.

Haraway, Donna. 2016. Staying with the trouble: Making kin in the chthulucene. Durham: Duke University Press.

Hecht, Gabrielle. 2018. 'Interscalar vehicles for an African anthropocene: On waste, temporality, and violence'. Cultural Anthropology 33 (1): pp. 109-141.

Holmes, Charles, Anthony Lake and Witney Schneidman. 2020. 'It's time to help Africa fight the virus'. Foreign Policy. Available at https://foreignpolicy.com/2020/04/29/ africa-coronavirus-pandemic-united-states-europe/. Accessed 7 November 2020.

Human Rights Watch. 2020. 'China: Covid-19 discrimination against Africans'. Available at https://www.hrw.org/news/2020/05/05/china-covid-19-discrimination-against -africans. Accessed 7 November 2020.

Gan, Elaine, Anna Tsing, Heather Swason and Nils Bubandt. 2017. 'Haunted landscapes of the anthropocene'. In Arts of living on a damaged planet: Ghosts and monsters of the anthropocene, edited by Anna Tsing, Nils Bubandt, Elaine Gan and Heather Anne Swanson. Minneapolis: University of Minnesota Press. Pp. G1-G16.

Izar, Priscila, Albert Nyiti, Elinorata Mbuya and Daniel Mbisso. 2020. 'The urban poor in sub-Saharan Africa under the corona virus pandemic: A view from Dar es Salaam, Tanzania'. Dar Es Salaam CityLAB. Available at https://www.africancentreforcities .net/blog-the-urban-poor-in-sub-saharan-africa-under-the-coronavirus-pandemic -a-view-from-dar-es-salaam-tanzania/. Accessed 7 November 2020.

Makoni, Munyaradzi. 2020. 'CoviD-19 in Africa: Half a year later'. The Lancet Infectious Diseases 20 (10): 1127.

Maqbool, Aleem. 2020. 'Coronavirus: Why has the virus hit African Americans so hard?'. ввс News. Available at https://www.bbc.com/news/world-us-canada-5224569o. Accessed 7 November 2020 .

Morita, Atsuro. 2017. 'Multispecies Infrastructure: Infrastructural Inversion and Involutionary Entanglements in the Chao Phraya Delta, Thailand'. Ethnos 82 (4): 738-757. 
Neavling, Steve. 2020. 'Black people make up $12 \%$ of Michigan's population - and at least $40 \%$ of its coronavirus deaths'. Metro Times. Available at https://www .metrotimes.com/news-hits/archives/2020/04/o2/black-people-make-up-12-of -michigans-population-and-at-least-40-of-its-coronavirus-deaths. Accessed 7 November 2020.

Omar, Yusuf Sheikh. 2020. 'Why is the Somali diaspora so badly hit by Covid-19?' African Arguments. Available at https://africanarguments.org/2020/05/13/why-is -the-somali-diaspora-so-badly-hit-by-covid-19/. Accessed 7 November 2020.

Onyango, Christopher. 2020. 'Special report: Diaspora remittances critical to post Covid-19 recovery'. comesa: Common Market for Eastern and Southern Africa. Available at https://www.comesa.int/wp-content/uploads/2020/o6/Diaspora -Remittances -Critical-for-Covid-19-Recovery.pdf. Accessed 8 November 2020.

Patton, Stacey. 2020. 'The pathology of American racism is making the pathology of the coronavirus worse'. Washington Post. Available at https://www.washingtonpost .com/outlook/2020/o4/11/coronavirus-black-america-racism/. Accessed 7 November 2020 .

Pilling, David. 2020. 'Africa's Covid-19 response is a glimpse of how things could be different'. Financial Times. Available at https://www.ft.com/content/124dd4f 4 - $8 \mathrm{aob}$ -11ea-9dcb-fe6871f4145a. Accessed 7 November 2020.

Simone, AbdouMaliq. 2004. 'Transversals of trauma through urban Africa'. In Urban Traumas. The City and Disasters. Center of Contemporary Culture of Barcelona, 711 July 2004.

Strathern, Marilyn. 1991. Partial Connections. Savage: Rowman \& Littlefield.

Vinga, Alois. 2020. 'Zimbabwe: Zim diaspora remittances set to dry during COVID-19 aftermath - World Bank'. New Zimbabwe. Available at https://www.newzimbabwe .com/zim-diaspora-responses-set-to-dry-during-covid-19-aftermath-world-bank/. Accessed 8 November 2020.

Waters, Mary C. 2013. Rising Nativism and Changing Racism: A New Form of American Exclusion. Max Planck Institute for the Study of Religious and Ethnic Diversity. Available at https://www.mmg.mpg.de/68905/online-lecture-2013-04-o9-waters. Accessed 7 November 2020.

Zane, Damian. 2020. 'Coronavirus: What African countries are doing to help people to eat amid the lockdowns'. ввс News. Available at https://www.bbc.com/news/world -africa-52426040. Accessed 7 November 2020. 